\title{
Examining the controls on overbank flood recharge for improved estimates of national water accounting
}

\author{
$\underline{\text { R.C. Doble }}^{\text {a }}$, R.S. Crosbie ${ }^{\text {a }}$, B.D. Smerdon ${ }^{\text {a }}$ and L. Peeters ${ }^{\text {a }}$ \\ ${ }^{a}$ Water for a Healthy Country, National Research Flagship, CSIRO Land and Water, PMB 2 Glen Osmond, \\ SA, Australia, 5064 \\ Email: rebecca.doble@csiro.au
}

\begin{abstract}
An often neglected component of the groundwater balance in water accounting is episodic recharge from flooding. A process that is distinctly different from more commonly known bank storage or stream loss processes, direct infiltration from overbank flows is highly variable between catchments and difficult to quantify in the field. The volume of aquifer recharge can be very large compared with bank storage and annual rates of stream leakage, and often resets the water table in aquifers underlying floodplains. Although the infiltration process itself has been studied for decades, it becomes more complex where the infiltration is limited by the presence of a water table, which is common in floodplains adjacent to rivers. The dynamic interaction between the stream and the groundwater will also impact the process.
\end{abstract}

Modelling of the overbank flood recharge process was undertaken using a fully-coupled, surface-subsurface flow model to determine the prevailing characteristics of episodic aquifer recharge. The recharge volume through the floodplain was compared with aquifer hydraulic conductivity, and therefore transmissivity, the presence of a lower conductivity layer on the floodplain surface or clogging layer, status of the river connection with the alluvial aquifer (gaining or losing) and the height, areal extent and duration of the flood pulse. The effects of topographical irregularities, such as wetlands in the floodplain were also considered.

The modelled overbank flood recharge volume was found to increase linearly with flood height and horizontal extent, and increased non-linearly with the duration of the flood.

The modelling indicated that overbank flood recharge was limited by three processes:

1. Infiltration through the soil surface, which was controlled by inundation depth and extent, and most critically, the clogging layer soil type;

2. The available storage for infiltrated water in the unsaturated zone, which was predominantly limited by the depth to groundwater, particularly in losing stream conditions; and

3. The ability of the aquifer to transport the water away from the flooded area. The transmissivity of the aquifer was critical where infiltration was not limited by a clay clogging layer.

The duration of the flood became a limiting factor in systems with heavier clogging layers, where the unsaturated soil storage capacity had not been reached. Recharge volume was also sensitive to the presence of local depressions, which extended the duration of infiltration beyond the time when the flood wave had retreated back to the within the river banks.

The findings are currently being used to develop a methodology for estimating overbank flood recharge at a catchment scale for the purpose of the national water accounts and water resource assessment being undertaken in the Water Information Research and Development Alliance (WIRADA) project by CSIRO Water for a Healthy Country and the Bureau of Meteorology. The results have international implications for water resources management through improved estimates of aquifer recharge in floodplain systems.

Keywords: recharge; floods; groundwater - surface water interactions 
Doble et al., Examining the controls on overbank flood recharge for improved estimates...

\section{INTRODUCTION}

One component of the water balance that is often neglected in water accounting is the episodic recharge of aquifers during overbank floods. A process that is distinct from bank storage or stream losses, direct infiltration from overbank flows is highly variable between catchments and difficult to quantify in the field. Very little information exists to describe the physics governing this process in the context of surface watergroundwater interactions.

The advance of water across a land surface and subsequent infiltration during an overbank flow event is a problem that has been studied for decades in the field of agricultural irrigation (e.g. Lewis and Milne, 1938; Goswami, 2007; Rasmussen, 1994). The analytical solutions arising from these studies assume a semiinfinite soil profile, therefore the rate of infiltration is not limited by a shallow water table, nor influenced by a dynamic water table that varies in height as a result of bank storage. Without modification, the solutions do not allow for more complex soil profiles, most significantly the presence of a surface layer of lower permeability material such as deposited silts and clays. The floodplain is assumed to be planar and horizontal, therefore the importance of microtopography and localised depressions cannot be assessed.

To include the impacts of heterogeneity and dynamic water table boundaries, overbank flood infiltration may be modelled numerically. As it occurs episodically and outside of the river channel, however, the functionality to represent this process is not usually included in numerical models where rivers are represented as a linear network.

The response of unconfined aquifers to overbank flood recharge has been documented in the field (Macumber, 1983; Jolly, 1996; Jolly et al., 1998 and 1994; Dahan et al., 2008; Doble et al., 2011) and is usually identified by a rapid and sustained rise in groundwater head. Modelling of the overbank flood recharge process in a sandy loam aquifer was undertaken by Doble et al. (2011) using HydroGeoSphere (Therrien et al., 2006) to determine the prevailing characteristics of piezometric response to overbank flood recharge. The modelling was able to reproduce the behaviour of test case observation bores in the Bremer River catchment at Langhorne Creek in South Australia, and gave a numerical demonstration of the flood recharge process.

This paper describes the development of a conceptual cross sectional model to study stream - aquifer interactions using HydroGeoSphere. This was used to determine the sensitivities of overbank flood recharge to parameters such as aquifer hydraulic conductivity, presence and type of clogging layers, stream - aquifer connection, flood wave characteristics and localised floodplain depressions such as wetlands.

\section{MODEL DEVELOPMENT}

Generic simulations of the overbank flood recharge process were undertaken for a sensitivity analysis of overbank recharge using physical properties based on previous studies of infiltration and flooding, and a numerical model was developed to calculate infiltration through the floodplain for each of these scenarios.

\subsection{Scenarios Modelled}

A total of 66 unique scenarios of various flood and aquifer conditions were modelled (Table 1). The scenarios modelled capture the effects of varying aquifer saturated hydraulic conductivity $\left(\mathrm{K}_{\mathrm{aq}}\right)$, flooding depth, horizontal extent and duration, the presence of a clogging layer overlying the floodplain and different stream - aquifer connections. An additional set of scenarios was developed to test the level of accuracy required in digital elevation map (DEM) data, which is often used to calculate flood extent from river stage data and therefore may be used in broad scale calculations of flood recharge. This was undertaken by modelling recharge from floodplains with several different amplitudes of elevation undulation, and one scenario that included a wetland.

\subsection{Model Structure}

The fully-coupled, surface-subsurface flow model HydroGeoSphere was used to determine the sensitivity of overbank flood recharge to the various soil and flood parameters. HydroGeoSphere simultaneously solves the diffusion-wave approximation of the Saint Venant equation for surface water flow and the Richards' equation governing 3-D unsaturated/saturated subsurface flow with a physical coupling between the two domains. The aquifer was conceptualised as a zone of porous media, overlain by overland flow cells (Figure 1). The overland flow cells allow the river to flow up its bank and over the floodplain, so that the river width 
Doble et al., Examining the controls on overbank flood recharge for improved estimates...

increases during high flows. The domains were linked with a dual node arrangement, with a coupling length of $0.01 \mathrm{~m}$.

Table 1 List of scenarios modelled. Note the number of models in each category counts models that are found in multiple categories as separate runs.

\begin{tabular}{|l|l|l|c|}
\hline $\begin{array}{l}\text { Sensitivity } \\
\text { parameter }\end{array}$ & $\begin{array}{l}\text { With varying wave or } \\
\text { clogging layer }\end{array}$ & Scenario & $\begin{array}{l}\text { Number } \\
\text { of models }\end{array}$ \\
\hline Clogging & $\begin{array}{l}\text { Standard flood wave and } \\
\text { indefinite flood wave }\end{array}$ & Eight clogging layer soil types & 16 \\
\hline Aquifer $\mathrm{K}_{\text {sat }}$ & $\begin{array}{l}\text { Clay, loam and sand clogging } \\
\text { layers }\end{array}$ & $\begin{array}{l}\text { Gravel, sand, sandy loam and } \\
\text { loamy sand aquifers }\end{array}$ & 12 \\
\hline $\begin{array}{l}\text { Stream } \\
\text { connection }\end{array}$ & $\begin{array}{l}\text { Clay, loam and sand clogging } \\
\text { layers }\end{array}$ & $\begin{array}{l}\text { Piezometric slopes of } 0.003,0, \\
-0.005 \text { and }-0.01\end{array}$ & 12 \\
\hline Wave height & $\begin{array}{l}\text { Clay, loam and sand clogging } \\
\text { layers }\end{array}$ & $\begin{array}{l}0 \mathrm{~m}, 0.5 \mathrm{~m}, 1.0 \mathrm{~m}, 1.5 \mathrm{~m}, \\
2.0 \mathrm{~m} \text { and } 2.5 \mathrm{~m} \text { wave heights } \\
\text { above bank full }\end{array}$ & 18 \\
\hline Wave duration & $\begin{array}{l}\text { Clay, loam and sand clogging } \\
\text { layers }\end{array}$ & $\begin{array}{l}\text { 0 day, } 2 \text { day, } 5 \text { day, } 10 \text { day } \\
\text { and 30 day wave peak } \\
\text { durations }\end{array}$ & 15 \\
\hline $\begin{array}{l}\text { Floodplain } \\
\text { undulations }\end{array}$ & Clay clogging layer & $\begin{array}{l}\text { Undulation amplitudes of } 0 \mathrm{~m}, \\
\text { 0.1 m, } 0.2 \mathrm{~m}, 0.5 \mathrm{~m} \text { and } 1.0 \mathrm{~m} \\
\text { Wetland } 200 \mathrm{~m} \text { wide, } 200 \mathrm{~m} \\
\text { from the river }\end{array}$ & 6 \\
\hline
\end{tabular}

The $1000 \mathrm{~m}$ wide, $35 \mathrm{~m}$ thick aquifer was modelled as homogeneous and isotropic with an impermeable base and no flow on the left (due to symmetry) and right boundaries. Rainfall and evapotranspiration were not considered in this study. Flow in the river was not simulated, but represented using a time-variable head boundary in the surface water domain. The model was run using the finite difference approach. To maintain a high level of accuracy when simulating coupled flows across the surface and variably saturated subsurface, the model required localised spatial discretisation near the river to $0.1 \mathrm{~m}$ horizontally, and $0.05 \mathrm{~m}$ vertically. Further from the river, a coarser spatial discretisation of $10 \mathrm{~m}$ was applied. Adaptive timestepping was used, with a maximum timestep of 0.1 days. Initial conditions included a constant pressure head within the aquifer and river, with an aquifer saturated thickness of $32 \mathrm{~m}$ and initial river depth of $2.0 \mathrm{~m}$. The model was initially run in steady state to obtain an initial water content profile for the unsaturated zone. Initial saturation conditions were not included in the sensitivity analysis.

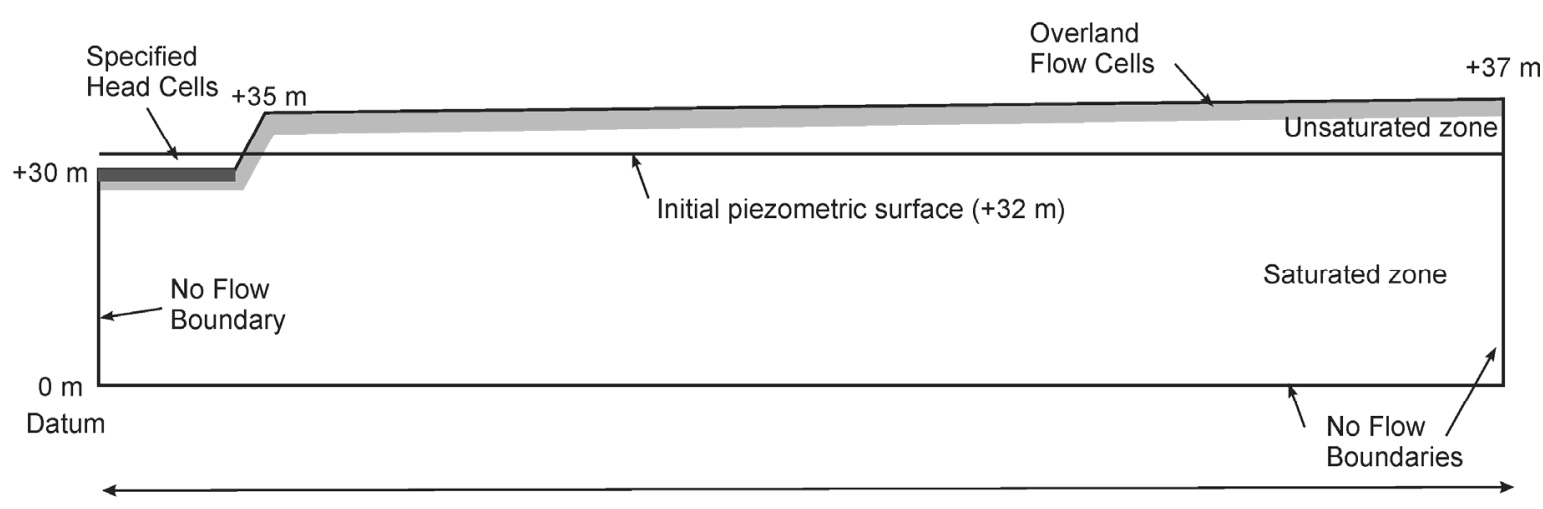

$1000 \mathrm{~m}$

Figure 1 Aquifer cross section used in this study (z dimension exaggerated)

The overland flow parameters consisted of a friction factor (Manning's $\mathrm{n}$ ) of $0.01 \mathrm{~s} \mathrm{~m}^{-1 / 3}$ in both $\mathrm{x}$ and $\mathrm{y}$ directions and rill storage height (the height of surface undulations that must be overtopped for flow to occur) of $0.01 \mathrm{~m}$. Soil parameters for the porous media domain, including van Genuchten (1980) parameters $(\alpha, \mathrm{n}$, saturated water content $\theta_{\mathrm{s}}$ and residual water content $\theta_{\mathrm{r}}$ ) for the unsaturated zone were based on a sand from the soil types described in Carsel and Parrish (1988). The top $0.2 \mathrm{~m}$ of the aquifer was defined as a separate zone to represent a clogging layer, and the soil type of the clogging layer was varied based on eight different 
Doble et al., Examining the controls on overbank flood recharge for improved estimates...

soil types from Carsel and Parrish (1988): sand, loamy sand, sandy loam, sandy clay loam, loam, silty clay loam, silt and clay.

The river flood pulse was modelled using a specified head boundary applied to model cells within the permanently saturated overland flow cells at the base of the river (Figure 1). The wave height was varied for different scenarios, but consisted of an initial rise over 5 days, a linear decrease to one quarter of the maximum stage from day 5 to day 10 , then a linear decrease to the original stage from day 10 to day 30 .

Maximum wave heights of $35 \mathrm{~m}, 35.5 \mathrm{~m}, 36 \mathrm{~m}, 36.5 \mathrm{~m}, 37 \mathrm{~m}$ and $37.5 \mathrm{~m}$ were used to represent within bank and overbank floods. The standard flood wave used in the scenarios modelled, unless specified otherwise, had a maximum wave height of $36 \mathrm{~m}$, corresponding to an elevation over bank full of $1.0 \mathrm{~m}$, and a peak duration of zero days. Flood waves with peak durations of 0 days, 2 days, 5 days, 10 days and 30 days were used to represent different flood durations and an indefinite flood wave was used to determine aquifer response to long-term pooling of water on the surface.

A selected number of example flood waves are shown in Figure 2.

Four different degrees of floodplain surface elevation irregularity were simulated using a sinusoidal undulation applied over the original, sloping floodplain surface. The undulation wavelength was $100 \mathrm{~m}$, and amplitudes of $0.1 \mathrm{~m}, 0.2 \mathrm{~m}, 0.5 \mathrm{~m}$ and $1.0 \mathrm{~m}$ were used. In addition to this, one model was developed using a standard floodplain with a $200 \mathrm{~m}$ wide wetland, $200 \mathrm{~m}$ from the river bank, with a depth of 2.4 metres.

The rate of infiltration through the floodplain surface, not including the

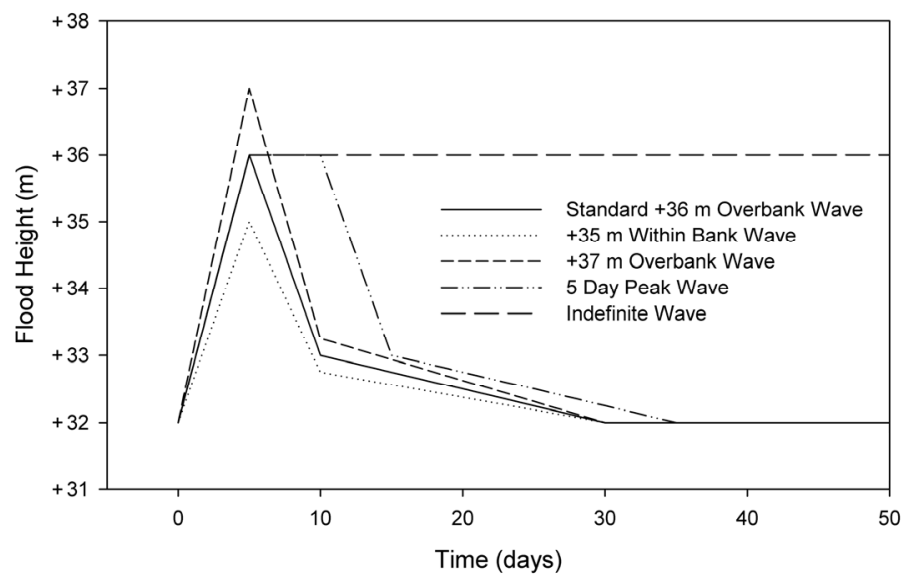

Figure 2 Example input flood waves, including the standard $36 \mathrm{~m}$ overbank wave, $35 \mathrm{~m}$ within bank and $37 \mathrm{~m}$ overbank waves, a 5 day peak wave and indefinite flood wave. volume infiltrated through bank storage, was extracted from the model results, and integrated over the 90 day modelling period to calculate the total volume of infiltration. Whilst the nature of the fully-coupled saturated - unsaturated model did not allow the recharge to the water table to be calculated, it is inferred by the volume of infiltration, and is equal to the infiltration volume minus the volume of water remaining in the unsaturated zone. As the model did not include evapotranspiration and consisted of a single flood pulse, it is a fair assumption that in time, the infiltrated volume will all reach the water table and the unsaturated zone will return to its pre-flood level of saturation.

\section{RESULTS}

Both the peak infiltration rate and duration of infiltration to the sand aquifer varied according to the soil type of the clogging layer (Figure 3). As expected, infiltration through soils with a high hydraulic conductivity, such as the sand, loamy sand or sandy loam peaked more quickly and reached a higher infiltration rate at the flood wave peak (5 days) than through the heavier clogging layers such as the clay. Conversely, as the unsaturated zones in the systems with the low conductivity clogging layers took longer to fill, the capacity for high rates of infiltration was extended for a longer period of time, and the shape of the curve reflects a

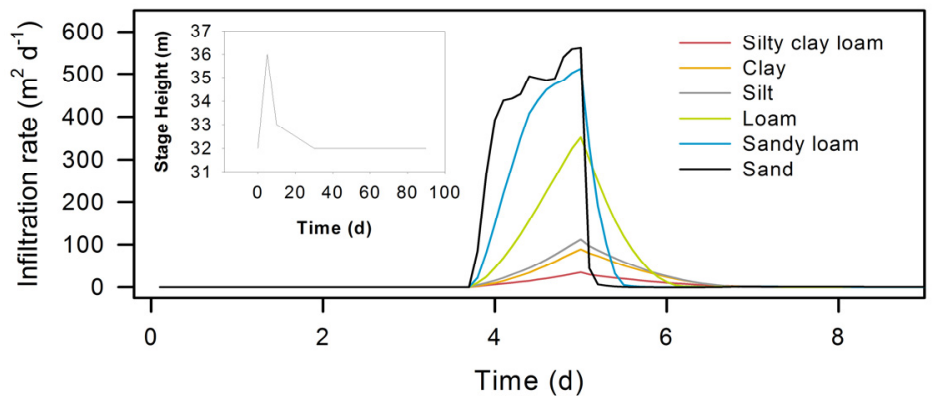
damped form of the input wave. Infiltration had almost ceased through the sand and loamy sand clogging layers less than half a day after the flood wave peak as the unsaturated zone filled very quickly and the head difference between the wave and the local groundwater tended to zero.

Figure 3. Infiltration rates for a sand aquifer with various clogging layer soil types. Soil types from Carsel \& Parrish (1988). 
Doble et al., Examining the controls on overbank flood recharge for improved estimates...

Plotting the clogging layer conductance against recharge (Figure 4a) shows a relatively linear relationship between a conductance of $0.24 \mathrm{~m}^{2} \mathrm{~d}^{-1}$ (clay) to $5.3 \mathrm{~m}^{2} \mathrm{~d}^{-1}$ (sandy loam). For clogging layers with a conductance higher than $5.3 \mathrm{~m}^{2} \mathrm{~d}^{-1}$ (loamy sand and sand) the reduced recharge volume indicates that the aquifer transmissivity, therefore transport of water away from the infiltration zone, was a limiting factor.

Figure $4 \mathrm{~b}$ shows the infiltration volume varying almost exactly with the square of the wave height $\left(\mathrm{R}^{2}>\right.$ 0.998), for all clogging layer soil types, as it also did for horizontal flood extent. As the floodplain that was modelled was sloping, the flood height and horizontal extent were related and therefore not independent variables. When the effects were separated by dividing the recharge by the horizontal extent or the wave height, the relationships with recharge increased linearly.

(a)

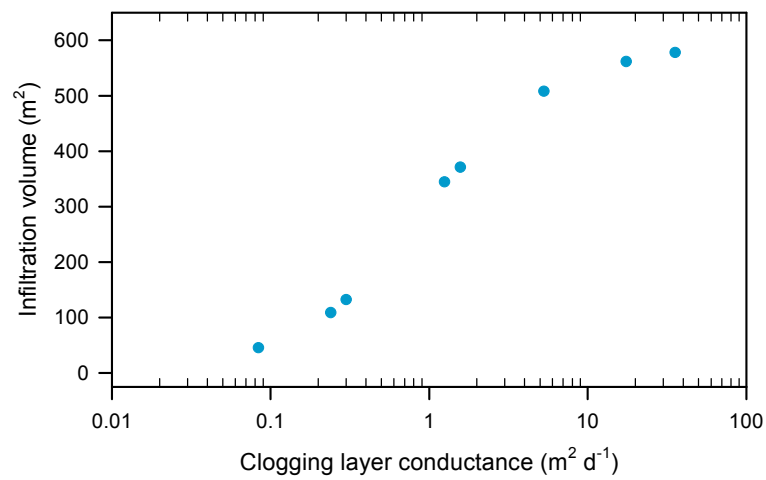

(c)

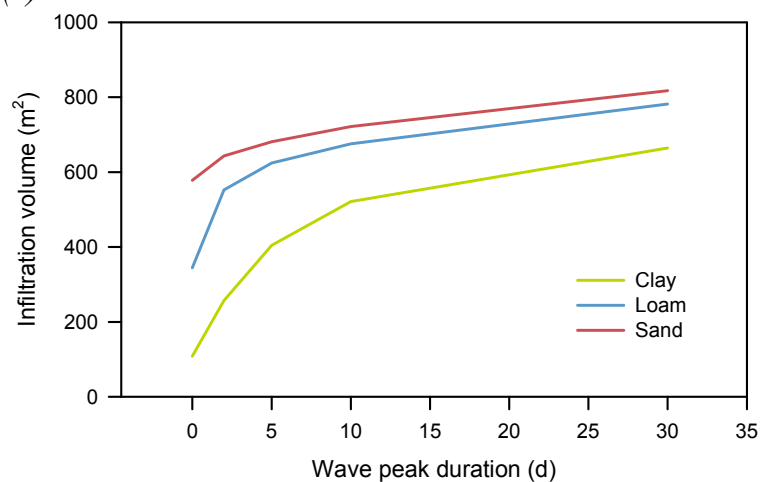

(e)

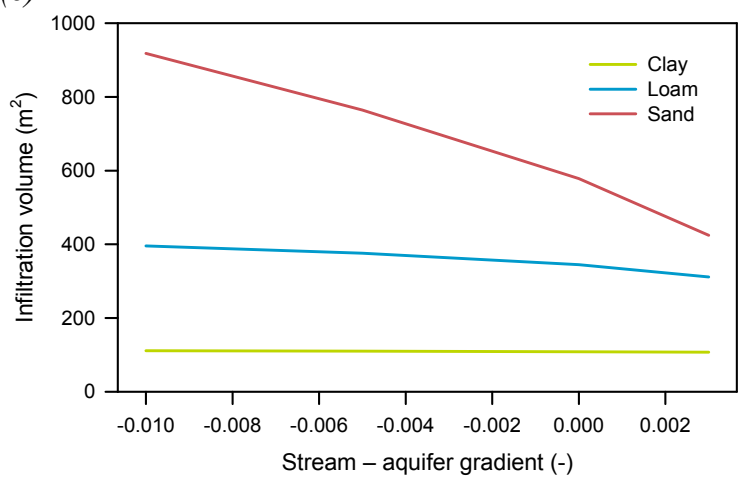

(b)

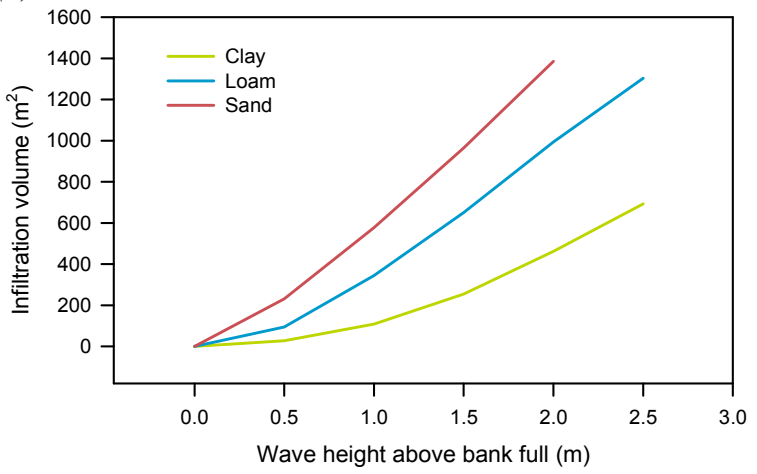

(d)

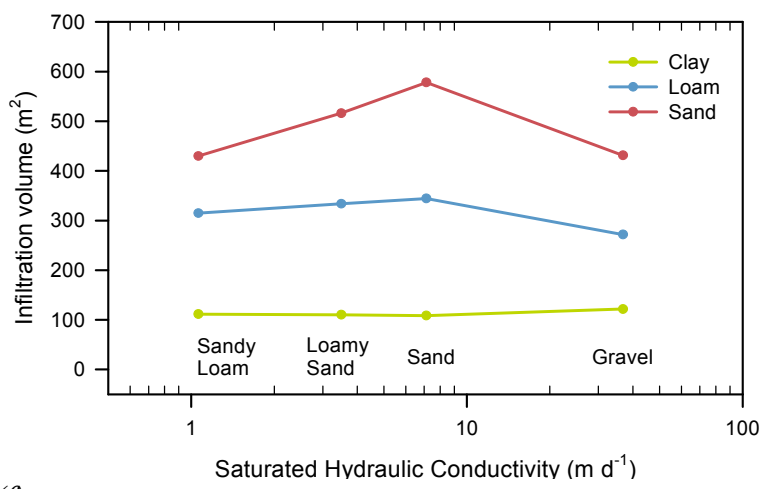

(f)

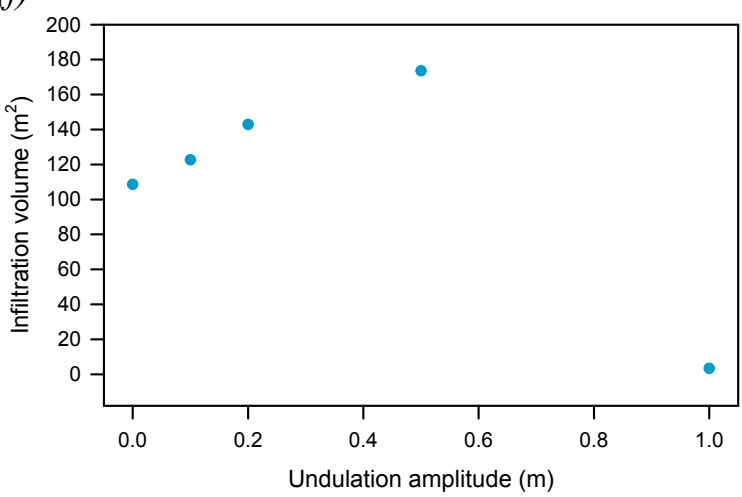

Figure 4. Recharge volume versus (a) clogging layer conductance, (b) flood wave height, (c) flood wave peak duration, (d) aquifer saturated hydraulic conductivity, (e) stream - aquifer gradient (positive indicates gaining stream) and (f) amplitude of floodplain undulations

Infiltration volume over the 90 day model period was plotted against the duration of the wave peak, for sand aquifers with clay, loam and sand clogging layers (Figure 4c). The infiltration volume for all three types of clogging layers increased with longer wave peak duration, but the clay responded more than the loam or the sand to the change, as the volume of water infiltrated was limited by the presence of the clogging layer rather than the aquifer storage or transmissivity. 
Doble et al., Examining the controls on overbank flood recharge for improved estimates...

For the sand, loamy sand and sandy loam aquifers, $\left(\mathrm{K}_{\mathrm{sat}}<10 \mathrm{~m} \mathrm{~d}^{-1}\right)$ in Figure $4 \mathrm{~d}$, increasing aquifer hydraulic conductivity, and therefore transmissivity, resulted in a larger infiltrated volume of water where the clogging layer did not significantly limit the infiltration rate. Figure $4 \mathrm{~d}$ shows that the infiltration volume increased with $\mathrm{K}_{\text {sat }}$ for a sand clogging layer, but had no perceivable increase for a clay clogging layer. For these three aquifer materials, the trend between $\mathrm{K}_{\text {sat }}$ and infiltration volume appears to be a logarithmic one. For the gravel aquifer $\left(\mathrm{K}_{\mathrm{sat}}=36 \mathrm{~m} \mathrm{~d}^{-1}\right)$, however, the infiltration volume is significantly less than for a sand or loamy sand aquifer. The reason for this is unclear, however, the advancing flood wave in the gravel appears to have very little vertical infiltration component compared with the horizontal infiltration from bank storage as the water table rises almost simultaneously with the advancing flood front. It is clear, however, that the increasing vertical recharge trend will break down for aquifers with very high hydraulic conductivity.

The stream - aquifer connection, defined as the hydraulic gradient of the water table (toward the river being positive), did not have any impact on infiltration volume for the system with a clay clogging layer (Figure $4 \mathrm{e})$. For the system with the sand clogging layer in particular, losing streams $(i<0)$ showed a much higher volume of infiltration than for neutral $(i=0)$ or gaining streams $(i>0)$. The higher volume of infiltration was due to an increased storage space in the losing river models, thereby allowing the aquifer to 'accept' more recharge. Additionally, the greater hydraulic gradient away from the losing rivers facilitates higher rates of water transport away from the floodplain, again allowing more recharge to take place.

Figure 4f shows the infiltration volume for various floodplain undulation amplitudes with a clay clogging layer. The figure shows increasing infiltration as the undulation elevation increases from zero as water is captured and held in the undulation depression, increasing the duration over which infiltration can take place. At values of dimensionless undulation amplitude higher than around 2.5, however, the undulation peaks are high enough to prevent passage of water across the floodplain, similar to a levee bank. Only the infiltration volume through a clay clogging layer is presented, as similarly to the wave duration scenario, the presence of undulations has a greater impact on recharge through clay soils than sands.

The impact of a $200 \mathrm{~m}$ wide wetland positioned $200 \mathrm{~m}$ from the river bank was to significantly increase the volume of infiltration from $109 \mathrm{~m}^{2}$ to $494 \mathrm{~m}^{2}$. The wetland also functioned by capturing surface water and holding it in place until it had infiltrated, effectively increasing the flood wave duration for that section of the floodplain. The graph of infiltration with time for the wetland scenario (not shown here) resembled that of the indefinite wave.

\section{DISCUSSION AND CONCLUSIONS}

The predicted linear relationships between overbank flood recharge volume and flood height and horizontal extent reflect the relationships previously described for infiltration from an advancing water front (Knight 1980). The analytical solutions of Knight (1980) also suggest that infiltration is linearly related to the duration of inundation. This is not obvious from the predicted relationships in this study (Figure 4c). The conceptual model in the Knight (1980) study, however, consisted of a free draining lower boundary condition, and therefore the impacts of a shallow water table on aquifer recharge are not included in their solutions. The modelling described in this paper predicted that recharge to an aquifer through a floodplain is limited by the capacity of the aquifer to store infiltrated water in the unsaturated zone and transport water away from the flooded area. This becomes more crucial for longer flood durations where unsaturated soil storage is filled.

It was evident from the modelling that the overbank flood recharge process was limited by three processes:

- Infiltration through the soil surface, which was controlled by inundation depth and extent, and most critically, the clogging layer soil type - this limitation was also noted in the study by Jolly et al. (1994);

- The available storage for infiltrated water in the unsaturated zone, which was predominantly limited by the depth to groundwater, indicated by greater volumes of recharge in losing stream conditions; and

- The ability of the aquifer to transport the water away from the flooded area. The hydraulic conductivity of the aquifer was critical here where infiltration was not limited by a clay clogging layer, and the higher gradients away from a losing stream also increase the potential for water transport and therefore aquifer recharge.

The duration of the flood became a limiting factor in systems with heavier clogging layers, where the unsaturated soil storage capacity had not been reached. 
Doble et al., Examining the controls on overbank flood recharge for improved estimates...

The infiltrated volume in the scenarios with floodplain undulations and a wetland was found to be very sensitive to the type and vertical extent of variations in topography. This has a relevance to the use of digital elevation maps (DEMs) and suggests that the highest possible level of accuracy be used for flood mapping and overbank flood recharge calculations. At worst, using data with a vertical resolution finer than the depth of flood inundation is advisable. This is especially important in environments where water will pool on the surface for long periods, such as those with heavy soil clogging layers. Knowledge of channel modifications, for example for flood irrigation purposes, is also important. Calculations for infiltration volume should be undertaken with caution in areas where topography impacts the duration of inundation.

The modelling described in this paper allowed the conceptual understanding of relationships between overbank recharge, flood and aquifer parameters to be developed and system limitations to be defined. The work will provide the basis for the development of equations and a methodology for calculating recharge in less data populated areas, which will be incorporated into the AWRA modelling system.

\section{ACKNOWLEDGMENTS}

This work is part of the water information research and development alliance between CSIRO's Water for a Healthy Country Flagship and the Bureau of Meteorology.

\section{REFERENCES}

Carsel, R.F. and Parrish, R.S. (1988) Developing joint probability distributions of soil water retention characteristics. Water Resources Research 24, 755-69.

Dahan, O., Tatarsky, B., Enzel, Y., Kulls, C., Seely, M., and Benito, G. (2008) Dynamics of Flood Water Infiltration and Ground Water Recharge in Hyperarid Desert. Ground Water 46(3), 450-461.

Doble, R.C., Crosbie, R.S., and Smerdon, B. D. (2011) Aquifer recharge from overbank floods. Conceptual and Modelling Studies of Integrated Groundwater, Surface Water and Ecological Systems (Proceedings of Symposium H01 held during IUGG2011 in July, 2011); Melbourne, Australia. IAHS Publication 345.

Goswami, M.D. (2007) Mathematical model on flow regime and water harvesting in inundation plains. Journal of the American Water Resources Association 43, 588-593.

Jolly, I.D. (1996) The Effects of River Management on the Hydrology and Hydroecology of Arid and SemiArid Floodplains. In 'Floodplain Processes.' (Eds Anderson, M.G., Walling, D.E. and Bates, P.D.) pp. 577609. (John Wiley \& Sons Ltd.: Chichester, New York.).

Jolly, I.D., Narayan, K.A., Armstrong, D., and Walker, G.R. (1998) The impact of flooding on modelling salt transport processes to streams. Environmental Modelling and Software 13(1), 87-104.

Jolly, I.D., Walker, G.R., and Narayan, K.A. (1994) Floodwater recharge processes in the Chowilla Anabranch system. Australian Journal of Soil Research 32, 417-35.

Knight, J. (1980) An Improved Solution for the lnfiltration-advance Problem in Irrigation Hydraulics. In: '7th Australasian Conference on Hydraulics and Fluid Mechanics 1980: Preprints of Papers. Barton, A.C.T., Australasian Conference on Hydraulics and Fluid Mechanics (7th: 1980: Brisbane, Qld.). pp. 25860. Institution of Engineers, Australia: National conference publication (Institution of Engineers, Australia); no. 80/4.

Lewis, M.R., and Milne, W.E. (1938) Analysis of border irrigation, Agricultural Engineering 19, $267-272$.

Macumber, P.G. (1983) Interactions between groundwater and surface systems in Northern Victoria. PhD Thesis, University of Melbourne.

Rasmussen, W.O. (1994) Infiltration-advance equation for finite linear source. Journal of Irrigation and Drainage Engineering-Asce 120, 796-812.

van Genuchten, M.Th. (1980) A closed-form equation for predicting the hydraulic conductivity of unsaturated soils. Soil Science of America Journal 44, 892-898.

Therrien, R., McLaren, R.G., Sudicky, E.A., and Panday, S.M. (2006) Hydrogeosphere-a three-dimensional numerical model describing fully-integrated subsurface and surface flow and solute transport. Groundwater Simul. Group, Waterloo, Ont., Canada., Université Laval, University of Waterloo. 